\title{
Plagiatlığın növləri və ondan qorunmağın üsulları
}

\author{
Rəhilə Həsənova ${ }^{1}$, Firudin Osgərov $^{2}$ \\ ${ }^{1,2}$ AMEA İnformasiya Texnologiyaları İnstitutu, Bakı, Azərbaycan \\ ${ }^{1}$ rahasanova@gmail.com, ${ }^{2}$ firudinasgarovegmail.com
}

\begin{abstract}
Xülasə- Məqalədə plagiatlıq və onun növləri araşdırılmış, antiplagiat sistemləri, onların əsas iş prinsipləri haqqında məlumat verilmişdir. Burada həmçinin Azərbaycan dilinə xas xüsusiyyətləri nəzərə alınmaqla təkliflər irəli sürülmüşdür.
\end{abstract}

Açar sözlor - plagiatlıq; antiplagiat sistemlori; PlagAware; PlagScan

\section{GİRIŞ}

Elmi informasiyanın sürətlə $\operatorname{artdı̆̆~}$ müasir dövrdə informasiyanın plagiat olub-olmamasını müəyyənləşdirən antiplagiat sistemlərinin işlənməsi aktual mövzulardandır.

Hazırda informasiya mənbələri daha çox elektron vasitələrdə mövcud olduğundan plagiatlıq da "elektron cinayət" kimi qiymətləndirilir. Təbii ki, bu halda plagiatlıqla mübarizənin əsas vasitəsi informasiyadan "qanuni" yolla istifadə imkanları yaradan yeni texnologiyaların yaradılması və istifadəsi başa düşülməlidir [1].

Plagiatlıq başqa müəllifə məxsus fikir və ideyaların öz adından təqdim olunmasına deyilir. $\mathrm{Bu}$ hadisə oğurluq və piratçılıqla S1X əlaqəlidir. Plagiatlıq kompüter virusları, spamlar, fişinq və s. kimi kibercinayətkarlığın bir növü hesab olunur. Plagiatlıq İnternetdən, kitabdan, jurnaldan və s. birbaşa mətnin köçürülməsi ilə və yaxud az sayda dəyişiklik etməklə baş verir [2].

Turnitin, Plagiarism və Research Resources antiplagiat sistemlərinə görə plagiatlıq aşağıdakı kimi təsnifləşdirilir [3-5]:

- Başqasının işinin özününki kimi təqdim edilməsi;

- Başqasına məxsus fikir və ideyalara istinad etmədən özününki kimi ifadə edilməsi;

- Başqasını ideyasının sitat şəklində yazılmaması;

- Sitatın mənbəsi haqqında yalnış məlumatın verilməsi;

- Sözləri dəyişərək mənbəyə istinad etmədən əsas strukturun olduğu kimi köçürülməsi;

- İstinad edilib-edilməməsindən asılı olmayaraq materialın əksər sözlərinin və ideyaların mənbələrdən istifadə edilməsi.

Ümumiyyətlə plagiatllı̆̆ iki əsas sinfə bölmək olar:

1. Mətn plagiatlı̆̆1. Bu tip plagiatlığ1 adətən elmi müəssisələrdə tələbələr və tədqiqatç1lar həyata keçirir. $\mathrm{Bu}$ zaman plagiatlıq mətni eynilə orijinal məqalənin, tezisin, elmi işin mətninə oxşayır.
2. Mənbə kodu plagiatlığı. Bu tip plagiatlıq yenə də tələbələr tərəfindən yerinə yetirilir, belə ki, onlar mənbəni qeyd etmədən oradakı bütün mətni və ya hər hansı bir hissəsini kod dəyişməklə köçürürlər. Bu tip plagiatlığ 1 təyin etmək çətin olur.

Mətn və mənbə kodu plagiatlığını 2 üsulla aşkarlamaq mümkündür: fiziki və avtomatik aşkarlama.

Fiziki aşkarlama o deməkdir ki, ekspert materialı özü yoxlayaraq onun plagiat olub-olmaması haqqunda qərar verir. Məsələn, müəllim tələbəyə verdiyi kurs işini özü şəxsən yoxlayır və onun orijinallığını qiymətləndirir. Lakin bu üsul çoxsaylı sənədlərin yoxlanması üçün effektiv deyildir, çünki bu proses müəllimdən çox vaxt və əmək tələb edir.

Avtomatik aşkarlama kompüter vasitəsilə həyata keçirilir, belə ki, avtomatik plagiatlığı aşkarlayan çoxlu sayda proqram təminatları movcuddur: PlagAware, PlagScan, Check for Plagiarism, iThenticate, PlagiarismDetection, Academic Plagiarism, The Plagiarism Checker, Urkund, Docoloc.

\section{PLAGİATLIĞIN NÖVLӘRİ}

Plagiatlığın aşağıdakı növləri vardır [5]:

I tip plagiatlıq: Birbaşa köçürtmək (eng. The Direct Copy). Müəllifin başqasının fraza, abzas və ya bütün səhifəsini sözbəsöz köçürərək öz adından ifadə etməsidir. 5 milyarda yaxın veb səhifənin içərisindən hər hansı bir sətri istinad etmədən köçürtmək onun gələcəkdə aşkarlanmayacağı demək deyildir. Son dövrlərdə bir çox elmi müəssisələr tədqiqatçılardan çap edilmiş əsərlərinin elektron variantını tələb edir, belə ki, onlar materialın plagiat olub-olmamasını müəyyənləşdirmək üçün axtarış aparırlar.

Həlli: Mənbəni ədəbiyyat siyahısına daxil etmək və istifadə olunmuş mətnin istinadını əlavə etmək lazımdır.

II tip plagiatlıq: Minimalist (eng. The Minimalist). Mənbə materialdan bir neçə söz və ya fraza dəyişdirilir, lakin əsas məzmun, struktur eynilə qalır. Fikri bu cür parafraz etmək onun orijinallığı demək deyil.

Həlli: Mənbəni ədəbiyyat siyahısına daxil etmək və yekun məzmunu öz sözlərinizlə ifadə edərək mətndaxili istinadlar vermək lazımdir.

III tip plagiatlıq: Birləşdirmok (eng. The Combo). Bunun gələcəkdə üstü açılmayacaq düşüncəsi ilə istifadə edilmiş informasiyanın müəyyən hissəsinə istinad verilir, digər hissələr isə istinadsız köçürülür. Bəzən tədqiqatçı elə düşünür 


\section{“Informasiya tohlükosizliyinin aktual multidissiplinar elmi-praktiki problemlori” IV respublika konfransı, 14 dekabr 2018-ci il}

ki, hamıya məlum ümumi informasiyaya istinad etmək lazım deyil.

Həlli: Bir qayda olaraq, hətta ümumi bilik hesab olunmayan bütün informasiya mənbələrinə istinad olunmalıdır.

IV tip plagiatlıq: Qarışdırmaq (eng. The Quilt). Bəzən müəlliflər bir neçə mənbədən istifadə etmələrinə baxmayaraq həmin mənbələrdən yalnız birinə istinad edirlər. $\mathrm{Bu}$ halda tədqiqatçı bir neçə müəllifin informasiyasını oğurlayaraq onların bir hissəsinə istinad etmiş olur. Bəlkə də bu halda tədqiqatçı materialı olduğunu iddia edərək plagiatçılıq etmir, lakin yanlış olaraq başqa mənbəyə istinad vermiş olur.

Həlli: İstifadə olunmuş mənbələrin hər birinə individual olaraq istinad etmək lazımdır. Təqdim edilmiş informasiyanın struktundan asılı olaraq bunu hər bir mənbə üçün ayrıca və ya hamısına ümumilikdə istinad şəklində vermək olar.

V tip plagiatlıq: Tutuquşu (eng. The parrot). Oksər tədqiqatçıların etdiyi yanlışlıq: onlar istifadə etdiyi mənbədən əsas strukturu və ideyanı köçürürlər. Müəlliflər istifadə etdikləri mənbədəki informasiyanı olduğu kimi köçürmürlər, əsas fikri öz sözləri ilə ifadə edirlər və düşünürlər ki, bu plagiatlıq deyil. Başqasına məxsus olan əsas fikir və ideyanın öz sözləri ilə ifadə olunması plagiatlıq faktıdır.

Həlli: Öz tədqiqat istiqamətini seçməklə, özünəməxsus nəticələrin əldə edilməsi.

VI tip plagiatlıq: Təhlükəli (eng. The Insecure). Bu vəziyyəti "Kiçik su pərisi komleksi" də adlandırırlar, belə ki, tədqiqatçı öz ideyasından imtina edərək yalnız başqalarının ideyasından istifadə edir. Yəni müəllif özünəməxsus ideyalardan deyil, tamamilə başqa müəlliflərə aid mənbələrə istinad olunan fikirlərdən ibarət məqalə yazır. Lakin, bu açıq şəkildə plagiatlıq hesab olunmasa da gələcək nəticələrə təhlükəli təsir göstərə bilər.

Həlli: Yadda saxlamaq lazımdır ki, akademik cəmiyyət sırf müəllifə aid olan ideyaları qəbul etmək istəyir. Buna görə də məqalələrdə öz şəxsi ideyalardan istifadə edilməlidir.

VII tip plagiatlıq: Dənizdə itmək (eng. The Lost-at-Sea). $\mathrm{Bu}$ vəziyyətlə məqalənin ədəbiyyat siyahısındak1 mənbələrin sayına tələb qoyulduğu zaman rast gəlmək olar. Məsələn, minimum 25 mənbənin adını qeyd etmək tələb olunduğu üçün müəllif 18 mənbədən istifadə etdiyi halda, siyahını süni şəkildə artırır. Hətta istifadə olunmamış, lakin ədəbiyyat siyahısında adı çəkilən mənbəyə istinad və ya uyğun olmayan mənbəyə istinad plagiatliq hesab olunur.

Həlli: Bunu yalnız istifadə olunmuş mənələrin adını ədəbiyyat siyahısına daxil etməklə çox sadə şəkildə həll etmək olur. Bu məsələ elektron ünvana da aiddir, belə ki, əgər mənbənin göstərdiyi sayt daha əlyetər deyilsə, onu yeniləmək lazımdir.

VIII tip plagiatlıq: Özünü izləmək (eng. The SelfObsessed). Müəlliflər düşünür ki, ideyaların özlərinə məxsus olması, bu ideyaların müxtəlif vaxtlarda, fərqli jurnallarda istifadə edilməsinə haqq qazandırır. Yazılmış məqalənin akademik cəmiyyətdə yeni formada təqdim edilməsi belə özünəplağiatlıq hesab olunur.

Həlli: Müəllif əvvəlki məqalələrini digər mənbələr kimi diqqətlə oxumalı və yeni ideyalardan istifadə etməlidir.

\section{ANTİPLAGİAT SİSTEMLӘRİ HAQQINDA}

Antiplagiat proqramları mətnin unikallığının qiymətləndirilməsi üçün işlənib hazırlanmış onlayn sistemlərdir. Antiplagiat sistemləri bir neçə əlamətə görə beş ulduzlu şkala ilə qiymətləndirilir [6]:

1. Verilənlər bazasının yoxlanması (eng. Database Checking). Bu yoxlama həm İnternet üzərindən, həm də lokal rejimdə verilənlər bazalarında axtarış etməyə imkan verir.

2. İnternet üzərindən yoxlama (eng. Internet Checking). Burada adi axtarış sistemi vasitəsilə cari sənədlə İnternetdə mövcud olan bütün növ sənədlərin müqayisəsi aparılır.

3. Nəşrin yoxlanması (eng. Publications Checking). Bu yalnız akademik bazalarda (Web of Science, Scopus və s.) mövcud olan sənədlərin - məqalə, tezis, kitab, jurnal və s. yoxlanmasıdır.

4. Fərqli sənədlərin eyni anda müqayisəsi (eng. Multiple Document Comparison). Bu xüsusiyyət bir neçə sənədi eyni anda paralel yoxlamağa imkan verir.

5. Müxtəlif əlifba və dillərin dəstəklənməsi (eng. Supported Languages). Burada müxtəlif dillərdə və əlifbalarda yazılmış mətnlərin yoxlanması həyata keçirilir.

6. Cümlə quruluşu və sinonimlər üzrə yoxlama (eng. Synonym and Sentence Structure Checking). Bu xüsusiyyət cümlə quruluşuna və sinonimlərin istifadəsinə görə sənədləri müqayisə edir.

Aşağıdakı cədvəldə bu əlamətlərə görə PlagAware, PlagScan, iThenticate, CheckFor Plagiarism və Plagiarism detecting antiplagiat sistemlərinin beş ulduzlu şkala ilə qiymətləndirilməsi təsvir edilmişdir [7].

Cədvəl 1. Antiplagiat sistemlərinin əlamətlərə görə qiymətləndirilməsi
\begin{tabular}{|l|l|l|l|l|l|}
\hline Olamətlər & PlagAware & PlagScan & iThenticate & $\begin{array}{l}\text { CheckFor } \\
\text { Plagiarism.net }\end{array}$ & $\begin{array}{l}\text { Plagiarism } \\
\text { detecting.org }\end{array}$ \\
\hline $\begin{array}{l}\text { Database } \\
\text { Checking }\end{array}$ & $* * * * *$ & $* * * * *$ & $* * * * *$ & $* * * *$ & $* * * *$ \\
\hline Internet Checking & $* * * * *$ & $* * * * *$ & $* * * * *$ & $* * * * *$ & $* * * * *$ \\
\hline $\begin{array}{l}\text { Publication } \\
\text { Checking }\end{array}$ & $* * * * *$ & $* * * * *$ & $* * * * *$ & $* * *$ & $* * *$ \\
\hline $\begin{array}{l}\text { Multiple } \\
\text { document } \\
\text { comparison }\end{array}$ & $* * * * *$ & $* * * * *$ & $* * * * *$ & $* * * *$ & $* * * *$ \\
\hline $\begin{array}{l}\text { Multiple } \\
\text { languages support }\end{array}$ & $* * * * *$ & $* * * * *$ & $* * * * *$ & $* * * * *$ & $* * * * *$ \\
\hline $\begin{array}{l}\text { Sentence structure } \\
\text { and synonym } \\
\text { checking }\end{array}$ & $* * * * *$ & $* *$ & $* * * *$ & $* * * * *$ & $* *$ \\
\hline
\end{tabular}

\section{NӘTİCO}

Mövcud antiplagiat sistemlərində çoxdillilik prinsipləri gözlənilsə də, hələlik dilin xüsusiyyətlərindən asılı olmayan 
universal antiplagiat sistemləri yaradılmamışdır. Buna görə də, hazırlanacaq antiplagiat sistemləri dilin xüsusiyyətlərini nəzərə almalıdır. Azərbaycan dili üçün aşağıdakı xüsusiyyətləri sadalamaq olar:

Antiplagiat sistemlərinin yalnız simvollarla deyil Screenshot vasitəsilə şəklini çəkib mətnləri oxşatmaqla qiymətləndirmək və ya mətnlərin avtomatik avtoreferatının çıxarılması və onların yoxlamaq.

Latın və kiril əlifbalarına uyğun mümkün variasiyaların yoxlanması, məsələn latın "o" və kiril "o" hərflərini yenidən dəyişərək yoxlama aparmaq. ASCII və Unicode əks kodlaşdırmasında mətni yenidən yoxlamaq.

\section{ӘDӘВIYYAT}

[1] R.Oliquliyev, N.Ağayev, R.Alıquliyev, "Plagiatlıqla mübarizo texnologiyaları”, Bakı: İnformasiya Texnologiyaları nəşriyyatı, 2015, $165 \mathrm{~s}$

[2] Encyclopedia Britannica, http://www.britannica.com/ EBchecked/topic/462640/plagiarism (last access February 7, 2011)

[3] Education with Integrity, Turnitin.com

[4] What is Plagiarism?, 2017, plagiarism.org
[5] M Asim, M. Hussam, V. Snasel, "Overview and Comparison of Plagiarism Detection Tools", Dateso 2011, pp. 161-172.

[6] How Do I Know If I'm Plagiarizing? https://www.scribendi.com/advice/how_do_i_know_if_im_plagiari zing.en.html

[7] Reliablex plagiarism detector, Plagiarismdetecting.org

\section{TYPES OF PLAGIARISM AND METHODS OF} PROTECTION

Rahila Hasanova $^{1}$, Firudin Asgarov ${ }^{2}$

${ }^{1,2}$ Institute of Information Technology of ANAS,

Baku, Azerbaijan

Abstract - The article examines plagiarism and its types, provides information on anti-plagirism systems, their basic principles of operation. Taking into account the characteristics of the Azerbaijani language, suggestions are put forward .

Keywords - plagiarism; anti-plagiarism systems; PlagAware; PlagScan 